\title{
EDITORIAL
}

\section{Greenland's Dilemma}

f all pristine lands that I have ever known, Greenland is unquestionably No. 1-and not merely in size. There, not so many years ago, one could wander for weeks on end without seeing a human being even in the most temperate part, the so-called 'banana belt' of the Julianehaab Distrikt of the extreme southwest; and when one did see any sign of Man it was apt to be quite a shock! Thus I remember once descending from the mountains in a fog to be confronted by the looming ruin of a tall Viking church when I did not know there was any still standing. One could even penetrate into unknown or at least unnamed valleys or other features-which subsequently became known by one's local cognomen because nobody else had (or anyway was known to have) ever been there. Thus they have I am told on the map now 'Rusekdalen' (the valley of the Russian, because of my name).

A Danish colony, Greenland was (and we understand still largely is) a 'closed country' which could be visited only with special permission and normally for approved scientific purposes; nevertheless it has some of the finest imaginable scenery, especially of tall mountains and deep fjords with glaciers calving into them. And like Iceland in some ways but quite differently in others, it has some of the most delightful and otherwise remarkable people, with a memorable culture of their own.

Now the 45,000-odd native Greenlanders, with home rule expected in the Spring of 1979, are showing growing opposition to any search for oil or gas around their shores. Almost in the manner of Iceland, their homeland is a (huge) "island surrounded by fish' and seals, and recently a new nationalist party was formed, inter alia to polarize this opposition. It is called Sujumut, which from my fleeting recollection of Greenlandic means something like 'Forward'.

According to the Financial Times of 7 September 1977, 'Greenlanders are somewhat suspicious of the outside world as represented both by the EEC [European Economic Community or 'Common Market'] and by the international oil companies.' Already in 1972 about two-thirds of the Greenland electorate voted against Danish membership of the EEC, much of this opposition being 'ascribed to fear that the Greenland fisheries interests would not be satisfactorily protected by the EEC. Moreover, it is clear to anyone who has talked with Greenlanders that there exists a simple and strong feeling that [they] do not have much in common with Europeans' (Ibid.), memorably hospitable though they were to the wandering 'Rusek' in bygone days.

Again according to the Financial Times, 'The oil search is the current issue on which the sense of opposition to foreign interests in Greenlandic affairs is finding expression. Six groups* were awarded concessions in 1973 to drill for and extract hydrocarbons from areas off the west coast of Greenland. A single well was drilled last year without finding anything. At least three more wells are being sunk this summer. The first well to be completed, by a group headed by Mobil, was dry. The prospects of finding hydrocarbons are regarded as good, although the finds will have to be large to make them worthwhile exploiting under the tricky conditions in the Davis Strait.'

The recent 'Bravo' blow-out in the Norwegian sector of the North Sea oilfields is reported to have caused a strong reaction in Greenland, where it is feared that any such event or a major tanker or other oil-spill would cause serious damage to the stocks and breeding- and nursery-grounds of important fishes (including salmon and cod) and seals on which the Greenlanders mainly live. Nevertheless the Danish Government refused to postpone this summer's drilling as requested by the majority of the Greenland Provincial Council (Greenland is constitutionally a Province of Denmark) and other Greenlandic interests. Their bases for this refusal were apparently 'that a blow-out from trial drilling was exceedingly unlikely and that safety precautions were rigorous'.

Such continuation of the search for oil and other sub-surface resources around and in Greenland is causing considerable apprehension and some resentment in the country. Nevertheless opposition is by no means universal among the widely-scattered native Greenlanders, and so one fears that, with home rule and cognate rights of full ownership of mineral and other natural resources, there might be temptations to relax controls and indulge in short-term, once-for-all financial gains to the detriment of renewable natural resources in the form of marine life which should be permanently conserved. Any such relaxation would seem unfortunate, indeed deplorably short-sighted, and should be resisted with the sympathetic support of all good conservationists and environmentalists-especially having regard to the notorious fragility of arctic ecosystems and the unfortunate ease with which fish-breeding can be disrupted.

N. P.

* According to J. Brøsted \& H. C. Gulløv (in Arctic: Journal of the Arctic Institute of North America, 30(2), p. 83, 1977), 'the new Danish government, formed after the general election of January 1975, approved the granting of some thirteen oil concessions off the coast of West Greenland. The concessionnaires were seven groups of nineteen foreign companies, and one consortium of eight larger Danish corporations'. 